\title{
HUBUNGAN ANTARA KECERDASAN EMOSIONAL DAN MOTIVASI BELAJAR DENGAN PRESTASI BELAJAR MATEMATIKA SISWA SMP
}

\author{
Arif Rahman Hakim ${ }^{1}$, Sulistiawati2, Samsul Arifin ${ }^{3}$ \\ 1,2,3 Sekolah Tinggi Keguruan dan IImu Pendidikan (STKIP) Surya \\ email: arif.rahman@students.stkipsurya.ac.id
}

\begin{abstract}
ABSTRAK
Rata-rata nilai Ujian Nasional (UN) matematika siswa SMP Negeri Kabupaten Kapuas Provinsi Kalimantan Tengah menunjukkan bahwa masih banyak siswa yang belum memiliki prestasi belajar matematika yang baik. Beberapa faktor yang mempengaruhi prestasi belajar matematika siswa adalah faktor kecerdasan emosional dan motivasi belajar. Penelitian ini bertujuan untuk mengetahui apakah terdapat: (1) hubungan positif antara kecerdasan emosional dengan prestasi belajar matematika siswa kelas IX SMP Negeri 1 Kapuas Barat, Kalimantan Tengah, (2) hubungan positif antara motivasi belajar dengan prestasi belajar matematika siswa kelas IX SMP Negeri 1 Kapuas Barat, Kalimantan Tengah, (3) hubungan positif antara kecerdasan emosional dan motivasi belajar dengan prestasi belajar matematika siswa kelas IX SMP Negeri 1 Kapuas Barat, Kalimantan Tengah. Penelitian ini menggunakan metode penelitian kuantitatif dengan jenis penelitian korelasional yang bertipe korelasi. Rancangan penelitian yang digunakan adalah regresi ganda dan korelasi ganda. Populasi penelitian ini adalah seluruh siswa kelas IX SMP Negeri 1 Kapuas Barat, Kalimantan Tengah dari kelas IX-A sampai IX-D yang berjumlah 81 siswa. Banyaknya sampel penelitian ditentukan berdasarkan tabel Krejcie dan Morgan (1970). Sampel penelitian ini berjumlah 66 siswa yang diambil dengan teknik simple random sampling. Hasil penelitian menunjukan bahwa: (1) terdapat hubungan positif antara kecerdasan emosional dengan prestasi belajar matematika siswa kelas IX SMP Negeri 1 Kapuas Barat, Kalimantan Tengah, hai ini ditunjukan dari nilai koefisien korelasi sederhana $r=0,389$ dan koefisien determinasi sebesar 15,158\%. (2) terdapat hubungan positif antara motivasi belajar dengan prestasi belajar matematika siswa kelas IX SMP Negeri 1 Kapuas Barat, Kalimantan Tengah, hai ini ditunjukan dari nilai koefisien korelasi sederhana $r=0,362$ dan koefisien determinasi sebesar $13,125 \%$. (3) terdapat hubungan positif antara kecerdasan emosional dan motivasi belajar dengan prestasi belajar matematika siswa kelas IX SMP Negeri 1 Kapuas Barat, Kalimantan Tengah, hal ini ditunjukan dari nilai koefisien korelasi ganda $R=0,545$ dan koefisien determinasi sebesar $29,668 \%$. Jadi, semakin tinggi kecerdasan emosional dan motivasi belajar siswa, maka semakin tinggi prestasi belajar matematika yang dicapai siswa.
\end{abstract}

Kata kunci: Kecerdasan Emosional, Motivasi belajar, Prestasi Belajar Matematika

Dikirim: 13 Agustus 2018; Diterima: 17 September 2018; Dipublikasikan: 29 September 2018

Cara sitasi: Hakim. A. R., Sulistiawati, dan Arifin. S. 2018. Hubungan antara Kecerdasan Emosional dan Motivasi Belajar dengan Prestasi Belajar Matematika Siswa SMP. Jurnal Teorema: Teori dan Riset Matematika. Vol 3 No 2, Hal 165-176, September 2018. 


\section{PENDAHULUAN}

Salah satu indikator keberhasilan dalam pendidikan adalah prestasi be lajar siswa-siswa dalam kategori baik, misalnya saja prestasi belajar dalam bentuk kognitif. Prestasi belajar dapat diartikan sebagai hasil yang telah dicapai atau diperoleh oleh seorang siswa setelah melakukan aktivitas belajar (Sardiman, 2016). Prestasi belajar yang telah dicapai/diperoleh oleh siswa dapat mencerminkan tingkat keberhasilan atau kemampuan siswa atas apa yang telah dipelajarinya. Prestasi belajar umumnya dinyatakan dalam bentuk nilai, baik itu angka ataupun huruf dari hasil evaluasi guru. Ujian Nasional (UN) merupakan satu dari beberapa bentuk evaluasi yang dilakukan untuk mengukur tingkat keberhasilan siswa dalam mempelajari mata pelajaran tertentu. Ada beberapa mata pelajaran yang diikutsertakan dalam UN, salah satunya adalah mata pelajaran Matematika. Dari data UN di jenjang Sekolah Menengah Pertama (SMP) pada tahun 2015 dan 2016 memperlihatkan hasil bahwa nilai rata-rata UN matematika siswa SMP Negeri Kabupaten Kapuas, Kalimantan Tengah adalah 49,10 dan 34,42 dari nilai maksimal 100 (Puspendik, 2017). Nilai ratarata tersebut memperlihatkan bahwa masih banyak siswa yang belum memperoleh prestasi belajar matematika dalam kategori baik. Prestasi belajar matematika siswa dapat dipengaruhi oleh banyak faktor. Sayangnya seberapa besar pengaruh faktor-faktor tersebut belum dapat diketahui. Untuk itu perlu diselidiki seberapa besarnya hubungan faktor-faktor tersebut berpengaruh terhadap prestasi belajar matematika siswa.

Secara garis besar, faktor yang dapat mempengaruhi pencapaian prestasi belajar siswa dapat dibedakan menjadi dua, yaitu faktor internal dan faktor eksternal (Slameto, 2010). Lebih lanjut, Slameto (2010) mengemukakan bahwa faktor eksternal adalah faktor yang muncul dari luar diri siswa seperti sumber belajar, fasilitas belajar, lingkungan sekolah, guru, teman, orang tua dan lainlain. Sedangkan faktor internal adalah faktor yang ada di dalam diri siswa seperti kecerdasan, bakat, minat, motivasi, keadaan fisik, kemandirian, kelelahan jasmani dan kelelahan rohani. Pada penelitian ini, faktor-faktor yang akan diselidiki apakah memiliki pengaruh yang besar terhadap pencapaian prestasi belajar matematika siswa adalah faktor kecerdasan dan motivasi.

Dari banyaknya faktor yang dapat mempengaruhi prestasi belajar siswa, salah satunya adalah kecerdasan (Slameto, 2010). Zohar dan Marshall mengemukakan bahwa terdapat tiga macam kecerdasan yaitu Intellegence Quotient (IQ), Emotional Quotient (EQ), dan Spiritual Quotient (SQ) (Efendi, 2005). Penelitian ini akan fokus pada kecerdasan emosional sebagai faktor yang mempengaruhi prestasi belajar siswa. Kecerdasan emosional merupakan kemampuan untuk mengenali emosi diri sendiri dan orang lain, untuk memotivasi diri sendiri, dan untuk mengelola emosi diri sendiri dengan baik dan dalam berhubungan dengan orang lain (Goleman, 2016). Berdasarkan pendapat Goleman (2016) tersebut, kecerdasan emosional diduga mempunyai pengaruh besar terhadap prestasi belajar karena siswa yang tidak mampu mengelola emosi dengan baik ketika mengikuti proses pembelajaran maka siswa tersebut tidak akan mampu belajar dengan sebaik-baiknya. Misalnya, jika proses pembelajaran dilakukan siswa dengan emosi negatif seperti marah, sedih, depresi maka siswa akan sulit menerima pelajaran yang diajarkan oleh guru yang pada akhirnya dapat mengakibatkan rendahnya prestasi belajar siswa.

Selain kecerdasan emosional, faktor lain yang dapat mempengaruhi prestasi belajar siswa adalah motivasi (Slameto, 2010). Motivasi menurut Kamus Besar Bahasa Indonesia (2017) dapat diartikan sebagai dorongan untuk melakukan sesuatu dengan tujuan tertentu. Sedangkan motivasi belajar adalah kondisi yang mendorong seseorang untuk belajar. Sardiman (2016) mengemukakan bahwa motivasi belajar merupakan faktor psikis yang bersifat non-intelektual. Motivasi belajar memiliki peranan dalam hal penumbuhan gairah, merasa senang dan semangat untuk belajar (Sardiman, 2016). Dalam proses belajar mengajar, motivasi sangat besar peranannya terhadap prestasi belajar. Siswa yang memiliki motivasi tinggi akan memiliki banyak energi untuk belajar.

Dikirim: 13 Agustus 2018; Diterima: 17 September 2018; Dipublikasikan: 29 September 2018

Cara sitasi: Hakim. A. R., Sulistiawati, dan Arifin. S. 2018. Hubungan antara Kecerdasan Emosional dan Motivasi Belajar dengan Prestasi Belajar Matematika Siswa SMP. Jurnal Teorema: Teori dan Riset Matematika. Vol 3 No 2, Hal 165-176, September 2018. 
Sedangkan siswa yang tidak mempunyai motivasi belajar di dalam dirinya cenderung malas dan tidak memiliki semangat untuk belajar sehingga dapat mempengaruhi prestasi belajarnya. Sardiman (2016) mengemukakan bahwa untuk belajar sangat diperlukan adanya motivasi. Hasil belajar akan menjadi optimal, jika dilakukan dengan motivasi yang tinggi. Siswa yang memiliki motivasi belajar tinggi cenderung memiliki sikap positif untuk berhasil (Slameto, 2010). Lebih jauh lagi Eftafiyana et al (2018) menyatakan bahwa motivasi belajar dapat memberikan pengaruh terhadap tindakan siswa dalam mencapai tujuan yang berdampak pada naik atau meningkatnya hasil belajar.

Berdasarkan apa yang telah dikemukakan, pencapaian prestasi belajar matematika siswa dapat dipengaruhi oleh beberapa faktor, diantaranya kecerdasan emosional dan motivasi belajar. Oleh karena itu, penulis tertarik untuk meneliti lebih lanjut seberapa besar pengaruh kecerdasan emosional dan motivasi belajar siswa terhadap prestasi belajar matematika yang dicapai siswa.

\section{Kecerdasan Emosional}

Dalam Kamus Besar Bahasa Indonesia, kecerdasan adalah perihal cerdas, kesempurnaan perkembangan akal budi seperti kepandaian atau ketajaman pikiran. Syah (2010) mengartikan kecerdasan sebagai kemampuan seseorang untuk menghadapi atau menyesuaikan diri terhadap lingkungan dengan cara yang tepat. Sejalan dengan pendapat tersebut, Sukmadinata (2009) mengemukakan bahwa kecerdasan berkaitan dengan bagaimana cara seseorang berbuat, dengan cara yang cerdas atau berbuat dengan cara yang tidak cerdas. Perbuatan yang cerdas dapat diketahui dengan perbuatan yang cepat dan tepat (Satriani,2015). Berdasarkan uraian di atas, dapat disimpulkan bahwa kecerdasan merupakan kemampuan seseorang menghadapi atau menyesuaikan diri dengan lingkungan secara efektif, cepat dan tepat.

Selanjutnya untuk mengetahui pengertian dari kecerdasan emosional, akan dipaparkan terlebih dahulu apa itu emosi. Emosi berasal dari kata kerja bahasa latin yaitu movere yang berarti menggerakan atau bergerak, ditambah dengan awalan e sehingga memberi arti kecenderungan untuk bertindak (Goleman, 2016). Hal serupa juga dikemukakan oleh Efendi (2005) yang mendefinisikan emosi sebagai suatu perasaan dan pikiran-pikiran yang khas, suatu keadaan biologis dan psikologis, serta suatu rangkaian kecenderungan untuk bertindak. Sedangkan dalam Kamus Besar Bahasa Indonesia, emosi adalah keadaan dan reaksi psikologis dan fisiologis (gembira, sedih, haru, cinta) yang bersifat subjektif. Terdapat delapan jenis emosi yang dapat dialami oleh setiap orang, seperti yang dikemukakan oleh Goleman (2016) yaitu amarah, rasa sedih, rasa takut, kenikmatan, cinta, terkejut, jengkel, dan juga malu.

Efendi (2005) mengemukakan bahwa kecerdasan emosional merupakan kecerdasan yang fokusnya pada mengenali, merasakan, memahami, mengelola dan memimpin perasaan diri sendiri dan orang lain serta menerapkannya terhadap kehidupan pribadi dan orang lain. Menurut Salovey dan Mayer, kecerdasan emosional adalah kemampuan untuk mengenali emosi diri sendiri, mengelola, dan mengungkapkan emosi diri sendiri dengan tepat, memotivasi diri, mengenali orang lain, dan membina hubungan dengan orang lain (Khodijah, 2014). Selanjutnya menurut Lynn dalam (Nurjanah, 2013) kecerdasan emosional merupakan dimensi dari kecerdasan yang bertanggung jawab dalam mengatur diri sendiri dan hubungan dengan orang lain. Sedangkan menurut Goleman (2016) kecerdasan emosional merujuk pada kemampuan untuk mengenali emosi diri sendiri dan orang lain, memotivasi diri sendiri, dan kemampuan mengelola emosi diri sendiri dengan baik dan dalam hubungan dengan orang lain. Berdasarkan pendapat di atas, kecerdasan emosional adalah kemampuan seseorang dalam mengelola emosinya dan merespon emosi orang lain dengan baik terutama dalam membina hubungan dengan orang lain.

Dikirim: 13 Agustus 2018; Diterima: 17 September 2018; Dipublikasikan: 29 September 2018

Cara sitasi: Hakim. A. R., Sulistiawati, dan Arifin. S. 2018. Hubungan antara Kecerdasan Emosional dan Motivasi Belajar dengan Prestasi Belajar Matematika Siswa SMP. Jurnal Teorema: Teori dan Riset Matematika. Vol 3 No 2, Hal 165-176, September 2018. 
Terdapat lima dimensi atau aspek kecerdasan emosional seperti yang dikemukakan oleh Lanawati (1999) dan Lynn (2002). Lanawati (1999) mengembangkan masing-masing dimensi berdasarkan lima domain yang diungkapkan oleh Goleman (2016) dan Lynn (2002) mengembangkan masing-masing dimensi berdasarkan lima domain yang diungkapkan oleh Salovey dan Mayer (dalam Nurjanah 2013). Lima dimensi kecerdasan emosional menurut Lanawati (1999), yaitu kesadaran diri (self-awareness), pengendalian diri (self-control), motivasi diri sendiri (selfmotivation), empati (empathy), dan keterampilan sosial (social skill). Sedangkan lima dimensi kecerdasan emosional yang dikemukakan Lynn (2002), yaitu kesadaran diri dan kontrol diri (selfawareness and self-control), empati (empathy), keterampilan sosial (social expertness), kemampuan mempengaruhi orang lain (personal influence), dan berwawasan ke depan (mastery of vision).

Untuk mengetahui tingkat kecerdasan emosional seseorang terdapat beberapa instrumen pengukuran yang dikembangkan oleh pakar kecerdasan emosional seperti Bar-On Emotional Quotient Inventory (EQ-i), Trait Meta Mood Scale (TMMS) dan Mayer-Saiovey-Caruso Emotional Intelligence Test (MSCEIT). Instrumen ini menunjukkan tingkat kecerdasan emosional yang ditinjau dari dimensinya masing-masing. Di Indonesia juga telah dikembangkan instrumen penelitian yang mengukur tingkat kecerdasan emosional seseorang. Instrumen tersebut dikembangkan oleh Lanawati (1999) yaitu Emotional Intelligence Inventory (Ell). Instrumen ini dikembangkan berdasarkan instrumen yang telah dibuat Bar-On tahun 1997 yaitu Emotional Quotient Inventory (EQ-i) dan yang disusun oleh Salovey, et al. tahun 1996 yaitu Trait Meta Mood Scale (TMMS) (Lanawati 1999). Pada penelitian ini, peneliti menggunakan instrumen yang dikembangkan oleh Lanawati (1999) yaitu Emotional Intelligence Inventory (EII) untuk mengukur tingkat kecerdasan emosional siswa.

\section{Motivasi Belajar}

Uno (2016) berpendapat bahwa motivasi adalah dorongan yang timbul oleh adanya rangsangan dari dalam maupun dari luar sehingga seseorang memiliki keinginan untuk melakukan perubahan tingkah laku atau aktivitas tertentu lebih baik dari keadaan sebelumnya. Menurut Donald (Sardiman, 2016) motivasi adalah perubahan energi yang ada dalam diri seseorang ditandai dengan munculnya rasa dan dorongan untuk mencapai tujuan. Sedangkan Sardiman (2016) mendefinisikan motivasi sebagai daya pengerak yang terdapat di dalam diri seseorang untuk melakukan kegiatan tertentu demi tercapainya suatu tujuan. Berdasarkan dari apa yang telah dipaparkan dapat disimpulkan, motivasi merupakan suatu dorongan yang ada dalam diri seseorang untuk melakukan segala sesuatu dalam berbagai situasi untuk mencapai suatu tujuan tertentu.

Motivasi memiliki beberapa macam fungsi. Hamalik (dalam Mukhtar, 2015) mengemukakan bahwa fungsi motivasi yaitu: 1) Mendorong timbulnya suatu perbuatan; 2) Motivasi berfungsi sebagai pengarah. Artinya mengarahkan perbuatan yang kita lakukan untuk mencapai tujuan yang diinginkan; 3) Motivasi berfungsi sebagai penggerak, besar kecilnya motivasi akan menentukan seberapa cepat atau lambatnya suatu pekerjaan. Sedangkan Sardiman (2016) juga mengemukakan bahwa ada tiga fungsi motivasi yaitu: 1) Mendorong seseorang untuk berbuat, sebagai penggerak atau motor yang melepas energi. Motivasi dalam hal ini merupakan mesin penggerak dari setiap kegiatan yang akan dikerjakan; 2) Menentukan arah perbuatan, kearah tujuan yang hendak dicapai. Motivasi dapat memberikan arah dan menuntun kita untuk melakukan kegiatan yang harus dikerjakan sesuai dengan tujuan yang hendak dicapai; 3) Menyeleksi perbuatan, menentukan perbuatan-perbuatan apa yang harus dikerjakan yang sesuai untuk mancapai tujuan dengan tidak melakukan perbuatan-perbuatan yang tidak bermanfaat bagi tujuan tersebut.

Dikirim: 13 Agustus 2018; Diterima: 17 September 2018; Dipublikasikan: 29 September 2018

Cara sitasi: Hakim. A. R., Sulistiawati, dan Arifin. S. 2018. Hubungan antara Kecerdasan Emosional dan Motivasi Belajar dengan Prestasi Belajar Matematika Siswa SMP. Jurnal Teorema: Teori dan Riset Matematika. Vol 3 No 2, Hal 165-176, September 2018. 
Dalam hal belajar, Sardiman (2016) mengartikan bahwa motivasi belajar adalah keseluruhan daya pengerak yang ada dalam diri siswa sehingga menyebabkan terjadinya kegiatan belajar, yang menjamin kelangsungan kegiatan belajar, dan yang memberikan arah pada kegiatan belajar sehingga tujuan yang dikehendaki akan tercapai. Sedangkan menurut Uno (2016) motivasi belajar adalah dorongan internal atau eksternal pada siswa yang sedang belajar agar terjadi perubahan tingkah laku. Jadi, dapat disimpulkan bahwa motivasi belajar adalah dorongan yang muncul dalam diri seseorang baik itu secara internal dan eksternal yang menyebabkan terjadinya kegiatan belajar, menjamin terjadinya kegiatan belajar, dan yang memberikan arah pada kegiatan belajar untuk memperoleh hasil yang ingin dicapai. Siswa yang memiliki motivasi belajar baik akan memiliki dorongan yang kuat untuk belajar sehingga memiliki prestasi belajar yang lebih baik.

Motivasi belajar yang muncul dalam diri seseorang dapat digolongkan menjadi dua bagian yaitu motivasi intrinsik dan motivasi ekstrinsik. Sardiman (2016) mengemukakan bahwa motivasi intrinsik adalah motivasi yang muncul tanpa perlu rangsangan atau dorongan dari luar karena setiap orang selalu memiliki dorongan untuk melakukan sesuatu. Seseorang yang termotivasi secara intrinsik akan melakukan pekerjaannya dengan kemauannya sendiri karena mendapatkan pekerjaan itu menyenangkan tidak tergantung pada penghargaan dan paksaan dari orang lain. Misalnya, seorang siswa belajar dengan giat karena menyukai pelajaran tersebut. Sedangkan motivasi ekstrinsik adalah motivasi yang muncul jika ada rangsangan dari luar. Motivasi ekstrinsik dapat disebabkan oleh keinginan menerima ganjaran atau menghindari hukuman (Sardiman, 2016). Misalnya, seorang siswa mengerjakan tugas karena takut dihukum oleh guru atau karena ingin mendapatkan hadiah. Uno (2016) juga berpendapat bahwa motivasi intrinsik merupakan motivasi yang muncul dari dalam, seperti minat atau keingintahuan, tidak dalam bentuk-bentuk penghargaan atau hukuman. Sedangkan motivasi ekstrinsik ialah motivasi yang muncul karena keinginan menerima ganjaran atau menghindari hukuman.

Terdapat beberapa macam indikator motivasi belajar. Sardiman (2016) mengemukakan bahwa indikator motivasi belajar adalah: (1) tekun menghadapi tugas; (2) ulet menghadapi kesulitan; (3) menunjukan minat terhadap bermacam-macam maslah; (4) lebih senang bekerja mandiri; (5) cepat bosan pada tugas-tugas yang rutin; (6) dapat mempertahankan pendapatnya; (7) tidak mudah melepaskan yang diyakininya; dan (8) senang memecahkan masalah soal-soal. Sedangkan Uno (2016) menyebutkan indikator motivasi belajar yang lain, yaitu: (1) adanya hasrat dan keinginan berhasil; (2) adanya dorongan dan kebutuhan dalam belajar; (3) adanya harapan atau cita-cita masa depan; (4) adanya penghargaan dalam belajar; (5) adanya kegiatan yang menarik dalam belajar; dan (6) adanya lingkungan belajar yang kondusif. Penelitian ini akan menggunakan beberapa indikator yang telah dikemukakan di atas, baik itu indikator secara intrinsik atau pun ekstrinsik.

\section{Prestasi Belajar Matematika}

Kata prestasi berasal dari bahasa Belanda yaitu prestatie. Dalam Kamus Besar Bahasa Indonesia prestasi adalah hasil yang dicapai dari apa yang telah dilakukan, dikerjakan, dan sebagainya. Hasil yang dimaksud dapat dinyatakan dalam bentuk angka atau dalam bentuk katakata. Sardiman (2016) juga menyatakan bahwa prestasi merupakan kemampuan yang diperoleh dari hasil interaksi antara berbagai faktor yang mempengaruhi seseorang baik dari dalam maupun dari luar ketika belajar. Selanjutnya, Sardiman (2016) mengemukakan bahwa belajar adalah perubahan tingkah laku pada diri atau penampilan, dengan serangkaian kegiatan seperti membaca, mendengarkan, mengamati, meniru, dan lain sebagainya. Syah (2010) menambahkan bahwa belajar merupakan perubahan seluruh tingkah laku pada diri seseorang yang relatif menetap sebagai hasil dari pengalaman dan interaksi dengan lingkungan yang membutuhkan proses kognitif.

Dikirim: 13 Agustus 2018; Diterima: 17 September 2018; Dipublikasikan: 29 September 2018

Cara sitasi: Hakim. A. R., Sulistiawati, dan Arifin. S. 2018. Hubungan antara Kecerdasan Emosional dan Motivasi Belajar dengan Prestasi Belajar Matematika Siswa SMP. Jurnal Teorema: Teori dan Riset Matematika. Vol 3 No 2, Hal 165-176, September 2018. 
Tingkah laku yang timbul akibat proses kematangan, keadaan gila, mabuk, lelah, dan jenuh tidak dapat disebut sebagai proses belajar. Berdasarkan pendapat di atas, dapat disimpulkan bahwa prestasi belajar merupakan hasil yang dicapai seseorang setelah melakukan aktivitas belajar baik berupa angka ataupun dalam bentuk kata-kata yang dapat mencerminkan tingkat penguasaan belajarnya.

Salah satu bidang studi yang dipelajari di sekolah adalah matematika. Matematika merupakan salah satu bidang studi yang memiliki peran penting dalam kehidupan sehari-hari serta berperan penting dalam berbagai disiplin ilmu, perkembangan sains dan teknologi modern saat ini. Oleh sebab itu, matematika merupakan salah satu bidang studi yang hampir selalu ada dan diajarkan disetiap jenjang pendidikan, mulai dari sekolah dasar hingga ke jenjang perguruan tinggi.

James dalam kamus matematikanya mengemukakan bahwa matematika merupakan ilmu tentang logika, mengenai bentuk, susunan, besaran, dan konsep-konsep yang saling berhubungan satu dengan yang lainnya, matematika terbagi ke dalam tiga bagian besar yaitu aljabar, geometri, dan analisis (Hasratuddin, 2013). Tetapi, ada pendapat lain yang mengemukakan bahwa matematika dibagi menjadi empat bagian yaitu aritmatika, aljabar, geometri dan analisis. Sementara itu, Prihandoko (2006) berpendapat bahwa matematika berkaitan dengan struktur-struktur, hubungan-hubungan, dan konsep-konsep abstrak yang dikembangkan dengan aturan-aturan yang logis. Sedangkan Susanto (2013) menyatakan bahwa matematika adalah salah satu ilmu yang dapat meningkatkan kemampuan berpikir, berargumentasi, dapat membantu dalam penyelesaian maslah dikehidupan sehari-hari, didunia kerja, serta berperan penting dalam perkembangan ilmu pengetahuan dan teknologi. Dari uraian di atas ditarik kesimpulan bahwa matematika adalah ilmu tentang logika, mengenai bentuk, susunan, besaran, struktur-struktur, hubungan-hubungan dan konsep-konsep abstrak yang saling berhubungan satu dengan lainnya dan dikembangkan dengan aturan logis yang dapat meningkatkan kemampuan berpikir, berargumentasi, dapat membantu dalam penyelesaian maslah dikehidupan sehari-hari.

Berdasarkan uraian mengenai prestasi belajar dan matematika, maka dapat disimpulkan prestasi belajar matematika adalah hasil yang telah dicapai seorang siswa setelah melakukan kegiatan atau aktivitas belajar matematika. Hasil yang dicapai siswa biasanya dinyatakan dalam bentuk angka ataupun kata-kata yang dapat mencerminkan tingkat penguasaan belajar siswa. Hasil tersebut dapat dilihat dari buku rapor atau dilihat dari nilai ulangan siswa pada mata pelajaran matematika. Dalam penelitian ini prestasi belajar matematika siswa dilihat dari nilai ulangan akhir semester (UAS) pada mata pelajaran matematika selama satu semester pada semester kedua di Tahun Pelajaran 2016/2017.

\section{METODE PENELITIAN}

Penelitian ini menggunakan metode penelitian kuantitatif dengan jenis penelitian korelasional. Penelitian ini bertujuan untuk mengetahui hubungan antara kecerdasan emosional dan motivasi belajar dengan prestasi belajar matematika siswa kelas IX SMP Negeri 1 Kapuas Barat, Kalimantan Tengah. Penelitian ini memiliki tiga variabel, yaitu kecerdasan emosional sebagai variabel bebas pertama $\left(\boldsymbol{X}_{\mathbf{1}}\right)$, motivasi belajar sebagai variabel bebas kedua $\left(\boldsymbol{X}_{\mathbf{2}}\right)$ dan prestasi belajar matematika sebagai variabel terikat $(\boldsymbol{Y})$. Hubungan antara variabel yang akan diteliti dalam penelitian ini dapat digambarkan sebagai berikut (Sugiyono, 2014).

Dikirim: 13 Agustus 2018; Diterima: 17 September 2018; Dipublikasikan: 29 September 2018

Cara sitasi: Hakim. A. R., Sulistiawati, dan Arifin. S. 2018. Hubungan antara Kecerdasan Emosional dan Motivasi Belajar dengan Prestasi Belajar Matematika Siswa SMP. Jurnal Teorema: Teori dan Riset Matematika. Vol 3 No 2, Hal 165-176, September 2018. 


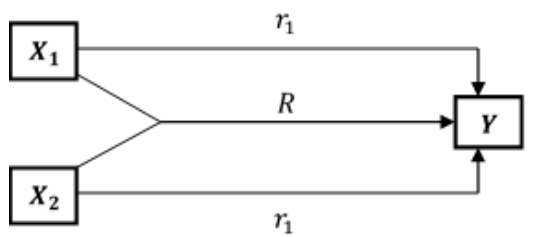

\section{Gambar 1. Bagan Hubungan antar Variabel}

Keterangan:

$$
\begin{array}{ll}
\boldsymbol{X}_{\mathbf{1}} & =\text { variabel Kecerdasan Emosional } \\
\boldsymbol{X}_{\mathbf{2}} & =\text { variabel Motivasi Belajar } \\
\boldsymbol{Y} & =\text { variabel Prestasi Belajar Matematika } \\
\boldsymbol{r}_{\mathbf{1}} & =\text { korelasi Sederhana antara } \boldsymbol{X}_{\mathbf{1}} \text { dengan } \boldsymbol{Y} \\
\boldsymbol{r}_{\mathbf{2}} & =\text { korelasi Sederhana antara } \boldsymbol{X}_{\mathbf{2}} \text { dengan } \boldsymbol{Y} \\
\boldsymbol{R} & =\text { korelasi Ganda antara } \boldsymbol{X}_{\mathbf{1}} \text { dan } \boldsymbol{X}_{\mathbf{2}} \text { dengan } \boldsymbol{Y}
\end{array}
$$

Populasi dalam penelitian ini adalah seluruh siswa kelas IX SMP Negeri 1 Kapuas Barat, Kalimantan Tengah tahun ajaran 2017/2018 berjumlah 81 siswa. Terdiri dari 4 kelas, siswa kelas IX.A, kelas IX.B dan kelas IX.C masing-masing berjumlah 20 siswa, sedangkan siswa kelas IX.D berjumlah 21 siswa. Banyaknya sampel dalam penelitian ini ditentukan berdasarkan tabel Krejcie dan Morgan (1970). Dari tabel tersebut diketahui bahwa untuk populasi yang berjumlah 81 orang maka banyaknya sampel penelitian adalah 66 orang. Pengambilan sampel dilakukan pada tiap kelas dengan menggunakan teknik simple random sampling dengan menggunakan rumus sebagai berikut (Sugiyono, 2014):

Keterangan:

$$
n_{i}=\frac{N_{i}}{N} \times n
$$

$\begin{array}{ll}\boldsymbol{n}_{\boldsymbol{i}} & =\text { banyaknya sampel di setiap kelas } \\ \boldsymbol{n} & =\text { banyaknya sampel penelitian } \\ \boldsymbol{N}_{\boldsymbol{i}} & =\text { banyaknya siswa di setiap kelas } \\ \boldsymbol{N} & =\text { banyaknya populasi penelitian }\end{array}$

Banyaknya sampel untuk setiap kelas dapat dilihat pada Tabel 1. berikut.

Tabel 1. Banyaknya Sampel Untuk Setiap Kelas

\begin{tabular}{cccc}
\hline No. & Kelas & $\boldsymbol{N}_{\boldsymbol{i}}$ & $\boldsymbol{n}_{\boldsymbol{i}}$ \\
\hline 1 & IX.A & 20 & 16 \\
2 & IX.B & 20 & 16 \\
3 & IX.C & 20 & 16 \\
4 & IX.D & 21 & 18 \\
\hline & & $\boldsymbol{N}=81$ & $\boldsymbol{n}=66$ \\
\hline
\end{tabular}

Teknik pengumpulan data yang digunakan pada penelitian ini menggunakan teknik kuesioner (angket) dan teknik dokumentasi. Kuesioner yang digunakan harus diuji validitas dan reliabilitasnya. Pengujian validitas menggunakan uji korelasi product moment dari Pearson dan pengujian reliabilitas menggunakan uji Cronbach Alpha. Sedangkan teknik analisis data dalam penelitian ini menggunakan uji regresi dan uji korelasi. Sebelum dilakukan analisis data, seluruh data ordinal dari angket yang diperoleh harus terlebih dahulu dikonversi ke jenis data interval dengan menggunakan Method of Successive Interval (MSI), selanjutnya dilakukan uji prasyarat normalitas,

Dikirim: 13 Agustus 2018; Diterima: 17 September 2018; Dipublikasikan: 29 September 2018

Cara sitasi: Hakim. A. R., Sulistiawati, dan Arifin. S. 2018. Hubungan antara Kecerdasan Emosional dan Motivasi Belajar dengan Prestasi Belajar Matematika Siswa SMP. Jurnal Teorema: Teori dan Riset Matematika. Vol 3 No 2, Hal 165-176, September 2018. 
linieritas, homoskedastisitas, dan uji multikolinieritas. Uji normalitas digunakan untuk menguji apakah data setiap variabel yang diambil dari sampel berdistribusi normal atau tidak. Uji linieritas digunakan untuk mengetahui apakah antara variabel bebas dan variabel terikat membentuk hubungan yang linear atau tidak. Uji homoskedastisitas digunakan untuk mengetahui kondisi varians dari residual pada model regresi cenderung konstan (Syifa, 2009). Uji moltikolinieritas digunakan untuk mengetahui kondisi apakah antara variabel-variabel bebas memiliki korelasi yang tinggi.

\section{HASIL DAN PEMBAHASAN}

Angket kecerdasan emosional yang peneliti gunakan dikembangkan oleh Dr. Sri Lanawati Raharja, S.Psi., M.Si. dosen jurusan psikologi di Universitas Pelita Harapan (UPH). Angket ini telah diujicobakan di dua lembaga pendidikan tinggi dan dua sekolah menengah umum dengan subjek penelitian untuk kelompok usia 16-25 tahun sebanyak 895 orang, 350 berjenis kelamin laki-laki dan 545 perempuan. Setelah dilakukan uji validitas dan uji reliabilitas didapat 80 butir pernyataan yang valid dan koefisien reliabilitas yang tinggi yaitu 0,9308 (Lanawati, 1999). Sedangkan angket motivasi belajar diujicoba ke siswa kelas IX SMP Negeri 2 Kapuas Barat, Kalimantan Tengah, sebanyak 42 siswa. Setelah dilakukan uji validitas dan uji reliabilitas didapat 25 butir pernyataan yang valid dengan koefisien reliabilitas yang tinggi yaitu 0,809 .

Seluruh data ordinal yang telah dikumpulkan dikonversi ke jenis data interval dengan menggunakan Method of Successive Interval (MSI). Selanjutnya dilakukan uji persyaratan analisis, yaitu uji prasyarat normalitas, linieritas, homoskedastisitas, dan uji multikolinieritas. Hasil pengujian diperoleh bahwa seluruh data memenuhi uji prasyarat tersebut, sehingga uji regresi dan korelasi dapat dilakukan.

Hasil uji regresi linear sederhana dan uji korelasi sederhana variabel kecerdasan emosional dan prestasi belajar matematika dapat dilihat pada tabel berikut ini.

Tabel 2. Hasil Uji Regresi Linear Sederhana dan Uji Korelasi Sederhana Variabel Kecerdasan Emosional dan Prestasi Belajar Matematika

\begin{tabular}{|c|c|c|c|c|c|c|}
\hline \multicolumn{7}{|c|}{ Uji Regresi Linear Sederhana } \\
\hline Variabel bebas & Variabel terikat & \multicolumn{2}{|c|}{ Persaman regresi } & $F_{\text {hitung }}$ & $F_{\text {tabel }}$ & Kesimpulan \\
\hline $\begin{array}{l}\text { Kecerdasan } \\
\text { Emosional }\end{array}$ & $\begin{array}{l}\text { Prestasi Belajar } \\
\text { Matematika }\end{array}$ & \multirow{2}{*}{\multicolumn{2}{|c|}{$\begin{array}{l}\widehat{\widehat{Y}} \\
=62,502+0,056 X_{1} \\
\quad \text { Uji Korelasi Sederha }\end{array}$}} & 11,43 & 3,99 & Tolak $\boldsymbol{H}_{\mathbf{0}}$ \\
\hline \multicolumn{5}{|c|}{ Uji Korelasi Sederhar } & & \\
\hline Variabel bebas & Variabel terikat & $\boldsymbol{r}$ & $D$ & $t_{\text {hitung }}$ & $t_{\text {tabel }}$ & Kesimpulan \\
\hline $\begin{array}{l}\text { Kecerdasan } \\
\text { Emosional }\end{array}$ & $\begin{array}{l}\text { Prestasi Belajar } \\
\text { Matematika }\end{array}$ & 0,389 & $15,158 \%$ & 3,382 & 1,998 & Tolak $\boldsymbol{H}_{\mathbf{0}}$ \\
\hline
\end{tabular}

Berdasarkan Tabel 2. diketahui bahwa nilai $\boldsymbol{F}_{\text {hitung }}=\mathbf{1 1}, \mathbf{4 3}$ yang diperoleh lebih besar dari nilai $\boldsymbol{F}_{\text {tabel }}=3,99$ sehingga kesimpulan dari uji regresi linier sederhana yaitu menolak $\boldsymbol{H}_{\mathbf{0}}$, yang artinya koefisien persamaan regresi antara variabel kecerdasan emosional dan prestasi belajar matematika bermakna. Dari uji korelasi sederhana, nilai $\boldsymbol{t}_{\text {hitung }}$ yang diperoleh adalah $\mathbf{3}, \mathbf{3 8 2}$, lebih besar dari nilai $\boldsymbol{t}_{\text {tabel }}=\mathbf{1 , 9 9 8}$ sehingga kesimpulan yang diperoleh juga menolak $\boldsymbol{H}_{\mathbf{0}}$, artinya terdapat hubungan antara variabel kecerdasan emosional dan prestasi belajar matematika. Nilai koefisien korelasi $\boldsymbol{r}>\mathbf{0}$, hal ini menunjukkan bahwa antara variabel kecerdasan emosional dan prestasi belajar matematika memiliki hubungan yang positif. Berdasarkan hasil tersebut maka terdapat hubungan positif antara kecerdasan emosional dan prestasi belajar matematika siswa kelas IX SMP Negeri 1 Kapuas Barat, Kalimantan Tengah.

Dikirim: 13 Agustus 2018; Diterima: 17 September 2018; Dipublikasikan: 29 September 2018

Cara sitasi: Hakim. A. R., Sulistiawati, dan Arifin. S. 2018. Hubungan antara Kecerdasan Emosional dan Motivasi Belajar dengan Prestasi Belajar Matematika Siswa SMP. Jurnal Teorema: Teori dan Riset Matematika. Vol 3 No 2, Hal 165-176, September 2018. 
Karena terdapat hubungan positif yang bermakna antara kecerdasan emosional dengan prestasi belajar matematika, maka untuk mengetahui besarnya pengaruh kecerdasan emosional terhadap prestasi belajar matematika dapat dilakukan dengan cara mencari koefisien determinasi. Hasil perhitungan diperoleh koefisien determinasi sebesar $15,158 \%$, artinya besarnya pengaruh kecerdasan emosional terhadap prestasi belajar matematika siswa adalah $15,158 \%$. Sedangkan $84,842 \%$ prestasi belajar matematika siswa dapat dipengaruhi oleh faktor-faktor lain.

Apa yang telah dibahas di atas sejalan dengan apa yang dinyatakan oleh Goleman (2016) yang menyatakan bahwa IQ hanya menyumbang sekitar $20 \%$ dalam menentukan prestasi individu, $80 \%$ sisanya ditemtukan oleh faktor lain salah satunya adalah kecerdasan emosional. Hal ini diperkuat dengan hasil penelitian yang telah dilakukan oleh Satriani (2015). Hasil penelitian Satriani (2015) menunjukan bahwa terdapat pengaruh yang positif antara kecerdasan emosional dan prestasi belajar matematika. Kecerdasan emosional memberikan pengaruh sebesar $26,9 \%$ terhadap prestasi belajar matematika.

Hasil uji regresi linear sederhana dan uji korelasi sederhana variabel motivasi belajar dan prestasi belajar matematika dapat dilihat pada tabel berikut ini.

Tabel 3. Hasil Uji Regresi Linear Sederhana dan Uji Korelasi Sederhana Variabel Motivasi Belajar dan Prestasi Belajar Matematika

\begin{tabular}{|c|c|c|c|c|c|c|}
\hline \multicolumn{7}{|c|}{ Uji Regresi Linear Sederhana } \\
\hline $\begin{array}{c}\text { Variabel } \\
\text { bebas }\end{array}$ & Variabel terikat & Persa & regresi & $F_{\text {hitung }}$ & $F_{\text {tabel }}$ & Kesimpulan \\
\hline $\begin{array}{l}\text { Motivasi } \\
\text { Belajar }\end{array}$ & $\begin{array}{l}\text { Prestasi Belajar } \\
\text { Matematika }\end{array}$ & $\widehat{Y}=64,4$ & $+0,153 X_{2}$ & 9,67 & 3,99 & Tolak $\boldsymbol{H}_{\mathbf{0}}$ \\
\hline \multicolumn{7}{|c|}{ Uji Korelasi Sederhana } \\
\hline $\begin{array}{c}\text { Variabel } \\
\text { bebas }\end{array}$ & Variabel terikat & $\boldsymbol{r}$ & $D$ & $t_{\text {hitung }}$ & $t_{\text {tabel }}$ & Kesimpulan \\
\hline $\begin{array}{l}\text { Motivasi } \\
\text { Belajar }\end{array}$ & $\begin{array}{l}\text { Prestasi Belajar } \\
\text { Matematika }\end{array}$ & 0,362 & $13,125 \%$ & 3,110 & 1,998 & Tolak $\boldsymbol{H}_{\mathbf{0}}$ \\
\hline
\end{tabular}

Berdasarkan Tabel 3. diketahui bahwa koefisien arah regresi antara variabel motivasi belajar dan prestasi belajar matematika bermakna. Hal ini diketahui dari nilai $\boldsymbol{F}_{\text {hitung }}=\mathbf{9 , 6 7}$ yang lebih besar dari nilai $\boldsymbol{F}_{\text {tabel }}=\mathbf{3 , 9 9}$ sehingga kesimpulan yang diperoleh menolak $\boldsymbol{H}_{\mathbf{0}}$. Hasil uji korelasi sederhana juga menunjukan bahwa nilai $\boldsymbol{t}_{\text {hitung }}=3,382$, lebih besar dari nilai $\boldsymbol{t}_{\text {tabel }}=1,998$ sehingga kesimpulan yang diperoleh menolak $\boldsymbol{H}_{\mathbf{0}}$, artinya terdapat hubungan antara variabel motivasi belajar dan prestasi belajar matematika. Nilai koefisien korelasi $\boldsymbol{r}>\mathbf{0}$, hal ini menunjukkan bahwa antara variabel motivasi belajar dan prestasi belajar matematika memiliki hubungan yang positif. Berdasarkan hasil tersebut maka terdapat hubungan positif antara motivasi belajar dan prestasi belajar matematika siswa kelas IX SMP Negeri 1 Kapuas Barat, Kalimantan Tengah.

Karena terdapat hubungan positif yang bermakna antara motivasi belajar dengan prestasi belajar matematika, maka untuk mengetahui besarnya pengaruh motivasi belajar terhadap prestasi belajar matematika yaitu dengan cara mencari koefisien determinasi. Koefisien determinasi diperoleh sebesar $13,125 \%$, artinya besarnya pengaruh motivasi belajar terhadap prestasi belajar matematika siswa adalah $13,125 \%$. Sedangkan $86,875 \%$ prestasi belajar matematika siswa dapat dipengaruhi oleh faktor lain.

Berdasarkan apa yang telah dipaparkan di atas, maka selain kecerdasan emosional, faktor lain yang dapat mempengaruhi prestasi belajar matematika adalah motivasi belajar. Sesuai dengan apa yang dikemukakan oleh Sardiman (2016) bahwa untuk belajar sangat diperlukan adanya motivasi. Hasil belajar akan optimal jika dilakukan dengan motivasi belajar yang tinggi.

Dikirim: 13 Agustus 2018; Diterima: 17 September 2018; Dipublikasikan: 29 September 2018

Cara sitasi: Hakim. A. R., Sulistiawati, dan Arifin. S. 2018. Hubungan antara Kecerdasan Emosional dan Motivasi Belajar dengan Prestasi Belajar Matematika Siswa SMP. Jurnal Teorema: Teori dan Riset Matematika. Vol 3 No 2, Hal 165-176, September 2018. 
Penelitian yang dilakukan oleh Mukhtar (2015) juga memperoleh hasil yang tidak jauh berbeda yaitu terdapat hubungan positif dan signifikan motivasi belajar dengan hasil belajar seni budaya pada bidang seni musik. Hal tersebut ditunjukan dari nilai koefisien korelasi yaitu $\boldsymbol{r}=\mathbf{0 , 4 9 2}$ yang berada pada kategori sedang.

Hasil uji regresi linear ganda dan uji korelasi ganda antara kecerdasan emosional dan motivasi belajar dengan prestasi belajar matematika dapat dilihat pada Tabel 4. berikut ini.

Tabel 4. Hasil Uji Regresi Linear Ganda dan Uji Korelasi Ganda Variabel Kecerdasan Emosional dan Motivasi Belajar dengan Prestasi Belajar Matematika

\begin{tabular}{|c|c|c|c|c|c|c|}
\hline \multicolumn{7}{|c|}{ Uji Regresi Linear Ganda } \\
\hline Variabel bebas & Variabel terikat & \multicolumn{2}{|c|}{ Persaman regresi } & $F_{\text {hitung }}$ & $F_{\text {tabel }}$ & Kesimpulan \\
\hline Kecerdasan & Prestasi Belajar & \multirow{2}{*}{\multicolumn{2}{|c|}{$\begin{array}{r}\widehat{Y}=50,269+0,059 X_{1} \\
+0,161 X_{2}\end{array}$}} & & & \\
\hline $\begin{array}{l}\text { Emosional dan } \\
\text { Motivasi Belajar }\end{array}$ & Matematika & & & 27,49 & 3,14 & Tolak $\boldsymbol{H}_{\mathbf{0}}$ \\
\hline \multicolumn{7}{|c|}{ Uji Korelasi Ganda } \\
\hline Variabel bebas & Variabel terikat & $\boldsymbol{R}$ & D & $t_{\text {hitung }}$ & $t_{\text {tabel }}$ & Kesimpulan \\
\hline Kecerdasan & Prestasi Belajar & & & & & \\
\hline $\begin{array}{l}\text { Emosional dan } \\
\text { Motivasi Belajar }\end{array}$ & Matematika & 0,545 & $29,668 \%$ & 13,287 & 3,143 & Tolak $\boldsymbol{H}_{\mathbf{0}}$ \\
\hline
\end{tabular}

Berdasarkan Tabel 4. diketahui bahwa koefisien arah regresi antara variabel kecerdasan emosional dan motivasi belajar dengan prestasi belajar matematika bermakna. Hal ini diketahui dari nilai $\boldsymbol{F}_{\text {hitung }}$ yang diperolah adalah 27,49 , nilai tersebut lebih besar dari nilai $\boldsymbol{F}_{\text {tabel }}=\mathbf{3 , 1 4}$ sehingga kesimpulan uji regresi linier ganda adalah menolak $\boldsymbol{H}_{\mathbf{0}}$. Uji korelasi ganda juga menunjukan bahwa terdapat hubungan antara variabel kecerdasan emosional dan motivasi belajar secara bersama-sama dengan prestasi belajar matematika. Hal ini diketahui dari hasil uji korelasi ganda diperoleh nilai $\boldsymbol{F}_{\text {hitung }}=13,287$ yang lebih besar dari nilai $\boldsymbol{F}_{\text {tabel }}=3,143$ sehingga kesimpulan yang diperoleh menolak $\boldsymbol{H}_{\mathbf{0}}$. Nilai koefisien korelasi $\boldsymbol{R}>\mathbf{0}$ menunjukkan bahwa antara variabel kecerdasan emosional dan motivasi belajar dengan prestasi belajar matematika memiliki hubungan yang positif. Berdasarkan hasil tersebut maka terdapat hubungan positif antara kecerdasan emosional dan motivasi belajar secara bersama-sama dengan prestasi belajar matematika siswa kelas IX SMP Negeri 1 Kapuas Barat, Kalimantan Tengah.

Karena terdapat hubungan positif yang bermakna secara bersama-sama antara kecerdasan emosional dan motivasi belajar dengan prestasi belajar matematika, maka untuk mengetahui besarnya pengaruh secara bersama-sama kecerdasan emosional dan motivasi belajar terhadap prestasi belajar matematika yaitu dengan cara mencari koefisien determinasi. Koefisien determinasi diperoleh sebesar $29,668 \%$, artinya besarnya pengaruh secara bersama-sama kecerdasan emosional dan motivasi belajar terhadap prestasi belajar matematika siswa adalah 29,668\%. Sedangkan 70,332\% prestasi belajar matematika siswa dapat dipengaruhi oleh faktor lain.

Berdasarkan apa yang dipaparkan di atas, kecerdasan emosional dan motivasi belajar secera bersama-sama diketahui memberikan pengaruh positif yang lebih besar terhadap prestasi belajar matematika. Seperti yang telah dibahas sebelumnya pada poin satu (1) dan dua (2), kecerdasan emosional memberikan pengaruh yang positif terhadap prestasi belajar matematika. Begitu juga dengan motivasi belajar, memberikan pengaruh positif terhadap prestasi belajar matematika. Oleh karena itu, jika kecerdasan emosional dan motivasi belajar digabungkan maka akan memberika pengaruh yang lebih besar terhadap prestasi belajar matematika.

Dikirim: 13 Agustus 2018; Diterima: 17 September 2018; Dipublikasikan: 29 September 2018

Cara sitasi: Hakim. A. R., Sulistiawati, dan Arifin. S. 2018. Hubungan antara Kecerdasan Emosional dan Motivasi Belajar dengan Prestasi Belajar Matematika Siswa SMP. Jurnal Teorema: Teori dan Riset Matematika. Vol 3 No 2, Hal 165-176, September 2018. 


\section{KESIMPULAN}

Kesimpulan yang dapat diambil berdasarkan uraian pada hasil penelitian dan juga pembahasan adalah bahwa:

1. Terdapat hubungan positif antara kecerdasan emosional dan prestasi belajar matematika siswa kelas IX SMP Negeri 1 Kapuas Barat. Koefisien korelasi antara kecerdasan emosional dan prestasi belajar matematika sebesar 0,389 dan koefisien determinasi sebesar 15,158\%.

2. Terdapat hubungan positif antara motivasi belajar dan prestasi belajar matematika siswa kelas IX SMP Negeri 1 Kapuas Barat. Koefisien korelasi antara motivasi belajar dan prestasi belajar matematika sebesar 0,362 dan koefisien determinasi sebesar 13,125\%.

3. Terdapat hubungan positif antara kecerdasan emosional dan motivasi belajar secara bersamasama dengan prestasi belajar matematika siswa kelas IX SMP Negeri 1 Kapuas Barat. Koefisien korelasi ganda antara kecerdasan emosional dan motivasi belajar dengan prestasi belajar matematika sebesar 0,545 dan koefisien determinasi sebesar $29,668 \%$.

\section{REKOMENDASI}

Penelitian ini memberikan hasil bahwa kecerdasan emosional dan motivasi belajar memberikan pengaruh yang positif terhadap prestasi belajar matematika siswa, baik pengaruh masng-masing atau secara simultan. Dengan demikian, ada baiknya guru pada saat pembelajaran memperhatikan unsur motivasi dan kecerdasan emosional tersebut. Pada saat pembelajaran, selain guru menyampaikan materi pelajaran juga memberikan motivasi baik di awal, tengah, atau akhir proses pembelajaran juga melakukan pengelolaan dan pengamatan terhadap emosi siswa selama proses pembelajaran berlangsung.

\section{UCAPAN TERIMAKASIH}

Peneliti ingin mengucapkan terima kasih kepada Ibu Dr. Sri Lanawati Raharja, S.Psi., M.Si, karena peneliti diberikan ijin menggunakan instrumen angket kecerdasan emosional yang telah beliau susun untuk penelitian ini. Selain itu peneliti juga ingin mengucapkan terima kasih kepada lbu Muliyani, S.Pd. selaku Kepala Sekolah SMP Negeri 1 Kapuas Barat yang telah memberikan ijin untuk penelitian dan Bapak Rudie, S.Pd. selaku Kepala Sekolah SMP Negeri Kapuas Barat yang telah memberikan ijin untuk melakukan uji coba instrumen.

\section{DAFTAR PUSTAKA}

Efendi, A. (2005). Revolusi Kecerdasan Abad 21. Bandung: Alfabeta.

Eftafiyana, S., et. al. (2018). Hubungan Antara Kemampuan Berpikir Kreatif Matematis dan Motivasi Belajar Siswa SMP yang menggunakann Pendekatan Creative Problem Solving. Jurnal Teori dan Riset Matematika (TEOREMA). Vol. 2 No. 2: 85-92.

Goleman, D. (1995). Emotional Intelligence. Terjemahan oleh Hermaya. (2016). Jakarta: Gramedia Pustaka Utama.

Hasratuddin. (2013). Membangun Karakter Melalui Pembelajaran Matematika. Jurnal Pendidikan Matematika PARADIKMA. Vol. 1 No. 2: 130-141.

Kamus Besar Bahasa Indonesia (KBBI). [Online]. Tersedia: http://kbbi.web.id [27 November 2017]. Khodijah, N. (2014). Psikologi Pendidikan. Jakarta: Rajawali Pers.

Dikirim: 13 Agustus 2018; Diterima: 17 September 2018; Dipublikasikan: 29 September 2018

Cara sitasi: Hakim. A. R., Sulistiawati, dan Arifin. S. 2018. Hubungan antara Kecerdasan Emosional dan Motivasi Belajar dengan Prestasi Belajar Matematika Siswa SMP. Jurnal Teorema: Teori dan Riset Matematika. Vol 3 No 2, Hal 165-176, September 2018. 
Krejcie, R. V., dan Daryle W. M. (1970). Determining Sample Size for Research Activities. Educational and Psychological Measurement, Vol. 30. [Online] Tersedia: https://home.kku.ac.th/sompong/guest_speaker/KrejcieandMorgan_article.pdf [20 Februari 2016].

Lanawati, S. (1999). Hubungan Antara Emotional Intelligence (EI) dan Inteligensi (IQ) dengan Prestasi Belajar Siswa SMU Methodist di Jakarta. Tesis. Universitas Indonesia Jakarta: Tidak dipublikasikan.

Lynn, A.B. (2002). The Emotional Intelligence Activity Book: 50 Activities For Promoting EQ At Work. New York: Amacom.

Mukhtar, R. (2015). Hubungan Motivasi Belajar dengan Hasil Belajar pada Mata Pelajaran Seni Budaya Bidang Seni Musik Siswa Kelas X SMA Piri 1 Yogyakarta. Skripsi. Universitas Negeri Yogyakarta: Tidak dipublikasikan.

Nurjanah, R. (2013). Hubungan Tingkat Partisipasi dalam Kegiatan Ekstrakulikuler dengan tingkat Kecerdasan Emosional siswa SMA N 14 Jakarta. Skripsi. Universitas Indonesia Jakarta: Tidak dipublikasikan.

Prihandoko, A. C. (2006). Memahami Konsep Matematika secara Benar dan Menyajikannya dengan Menarik. Jakarta: Departemen Pendidikan Nasional.

Puspendik. Indeks Integritas Ujian Nasional (IIUN) Tingkat Sekolah. [Online]. Tersedia: http://puspendik.kemdikbud.go.id/hasil-un/ [12 Januari 2017).

Sardiman, A.M. (2016). Interaksi dan Motivasi Belajar Mengajar. Jakarta: Raja Grafindo Persada.

Satriani, R. D. (2015). Pengaruh Kecerdasan Emosi Terhadap Prestasi Belajar Matematika Siswa Kelas V di SD Negeri Reowinangun 1 Yogyakarta. Skripsi. Universitas Negeri Yogyakarta: Tidak dipublikasikan.

Slameto. (2010). Belajar dan Faktor-Faktor yang Mempengaruhinya. Jakarta: Rineka Cipta.

Sugiyono. (2014). Metode Penelitian Kuantitatif, Kualitatif dan R\&D. Bandung: Alfabeta.

Sukmadinata, N. S. (2009). Landasan Psikologi Proses Pendidikan. Bandung: Remaja Rosdakarya.

Susanto, A. (2013). Teori Belajar \& Pembelajaran di Sekolah Dasar. Jakarta: Kencana.

Syah, M. (2010). Psikologi Pendidikan dengan Pendekatan Baru. Bandung: Remaja Rosdakarya.

Syifa, L. (2009). Pendeteksian Heteroskedasitas dengan Pengujian Korelasi Rank Sperman dan Tindakan Perbaikannya. Skripsi. Universitas Negeri Semarang: Tidak dipublikasikan.

Uno, H. B. (2016). Teori Motivasi \& Pengukurannya: Analisis di Bidang pendidikan. Jakarta: Bumi Aksara.

Dikirim: 13 Agustus 2018; Diterima: 17 September 2018; Dipublikasikan: 29 September 2018

Cara sitasi: Hakim. A. R., Sulistiawati, dan Arifin. S. 2018. Hubungan antara Kecerdasan Emosional dan Motivasi Belajar dengan Prestasi Belajar Matematika Siswa SMP. Jurnal Teorema: Teori dan Riset Matematika. Vol 3 No 2, Hal 165-176, September 2018. 